\title{
Use of radiotherapy after pituitary surgery for non-functioning pituitary adenomas
}

\author{
Philippe Chanson ${ }^{1,2,3}$, Alexandre Dormoy' ${ }^{1}$ and Olaf M Dekkers ${ }^{4}$ \\ ${ }^{1}$ Assistance Publique-Hôpitaux de Paris, Hôpital de Bicêtre, Service d'Endocrinologie et des Maladies de la \\ Reproduction, Centre de Référence des Maladies Rares de l'Hypophyse, Le Kremlin Bicêtre, France, ²Univ Paris-Sud, \\ Faculté de Médecine Paris-Sud, Univ Paris-Saclay, Unité Mixte de Recherche-S1185, Le Kremlin Bicêtre, France, \\ ${ }^{3}$ Institut National de la Santé et de la Recherche Médicale (INSERM), U1185, Le Kremlin Bicêtre, France, and \\ ${ }^{4}$ Departments of Clinical Epidemiology and Clinical Endocrinology, Leiden University Medical Centre, Leiden, \\ The Netherlands
}

Correspondence should be addressed to $\mathrm{P}$ Chanson or $\mathrm{O} \mathrm{M}$ Dekkers

Email

philippe.chanson@aphp.fr or O.M.Dekkers@lumc.nl

\begin{abstract}
Surgery is the treatment of choice for non-functioning pituitary macroadenomas (NFPAs). In cases of postoperative remnant growth or tumor recurrence, radiotherapy (RT) can be considered. The role of RT in the postoperative management of NFPAs is still debated. The main arguments against routine use of RT are the lack of randomized controlled trials, the use of clinically irrelevant endpoints in most studies on RT, the benign character of the condition, the potential for side effects of RT, and the option to apply RT at a later stage. However, because of its excellent efficacy in inhibiting tumor growth, reducing tumor volume and improving any existing visual defects, and as its side effects seem to be limited compared to the benefits provided, RT keeps a place in the management of NFPAs when a tumor remnant persists, particularly if it is invasive and displays high proliferation markers, if surveillance shows a relevant increase in tumor volume or if the tumor is close to the optic chiasm. The size of the remnant, its vicinity with the optic pathways, and the potential risk to healthy surrounding tissues need to be considered when deciding on an RT procedure.
\end{abstract}

Non-functioning pituitary adenomas (NFPAs) are benign tumors of the pituitary gland. For most newly discovered macroadenomas (i.e., pituitary tumors $>1 \mathrm{~cm}$ in diameter), surgery is the therapeutic approach of choice. The apparent benefits are mainly reduction in headache complaints (if present pre-surgery) and improvement in visual function $(1,2)$. Restoration of hormonal deficiencies is achieved less often. In cases of postoperative remnant growth or tumor recurrence, radiotherapy (RT) can be considered (3). Various RT techniques are currently available. Fractionated conformal RT (FCRT) delivers high-energy X photons, with a total dose between 45 and $50 \mathrm{~Gy}$, fractionated in 25 sessions of 1.8-2 Gy. Radiosurgery (SRS) delivers radiation in a single session. Gamma knife requires the use of an invasive stereotactic frame for precise positioning, while Novalis, Cyberknife or ICON gamma knife are frameless
European Journal of

Endocrinology

(2019) 181, D1-D13 facilities using thermoformable mask. The devices used are the Gamma Knife (201 ${ }^{60}$ Co sources on a hemisphere) and linear accelerator (LINAC). Fractionated stereotactic RT (FSRT) combines the ballistic precision and multiple beam entries of radiosurgery with the principle of healthy tissue radioprotection by fractioning. The total dose is 45-50 Gy, administered in fractions of 1.8-2 Gy. Hypofractionated stereotactic radiotherapy (in 3-5 five fractions mainly, delivering a total dose of 20-30 Gy) may also be proposed. Lastly proton beam therapy has also been used but very rarely in this condition (4).

The role of RT in the postoperative management of NFPAs is still debated. In the past, RT has been administered routinely after surgery to prevent regrowth of the remnant or recurrence of the adenoma. Nowadays, postsurgical RT is used less routinely, but there may

Published by Bioscientifica Ltd. 
be patients who will benefit from adjuvant therapy after surgery.

In the first section of this paper, OD will argue against the routine use of RT after surgery for NFPAs. The main arguments are the lack of randomized controlled trials, the use of clinically irrelevant endpoints in most studies on RT, the benign character of the condition, the potential for side effects of RT, and the option to apply RT at a later stage.

In the second section, $\mathrm{PC}$ and $\mathrm{AD}$ will provide arguments in favor of its use. Indeed, RT is very effective in controlling tumor growth and its side effects may appear moderate compared to the benefits provided.

The conclusion section will reconcile points of view by showing that both arguments should be considered in order to choose the best course of treatment for the patient on an individual basis.

\section{Arguments against the use of radiotherapy postoperatively}

\section{Lack of randomized controlled trials}

Let us set the record straight: there are no randomized controlled trials showing the superiority of RT compared to a conservative approach after surgery for nonfunctioning pituitary adenomas. There are also no randomized controlled trials comparing different RT procedures (conventional RT, SRS, FSRT) (5). For most drugs, this would be a sufficient argument not to use them in routine clinical practice. Why? Because we want our patients to be treated only with drugs that have withstood the highest level of scrutiny, i.e., a randomized controlled trial, and for which the benefit-risk assessment is considered positive. So why not simply abstain from RT, given this lack of randomized evidence?

In the absence of randomized trials, we often rely on observational studies to guide treatment. But such observational studies have clear and well-known limitations; however, the mere absence of randomized trials or reference to observational studies as 'real world data', by no means make observational studies valid. Important threats to the validity of observational studies include confounding by indication, non-standardized follow-up protocols and incomplete outcome reporting. Moreover, follow-up of patients and outcome assessment is often less stringent in an observational setting. This threatens not only the validity of direct comparisons between patients treated with and without RT within a study, but is also an issue when comparing cohorts of patients treated with and without RT across studies.

For example, how do we know with certainty that two groups of patients with NFPAs, one group treated with and one group without postoperative RT, have had a similar quality of surgery? This is especially relevant in a situation where results from different studies performed at different centers are compared. Similarly, can we be sure that characteristics of growth potential, size and localization of the residual tumor are well balanced between the groups to be compared? Is the follow-up protocol equal between the studies? Clearly, a more stringent protocol may detect regrowth earlier. The first two questions relate to the potential of differences in prognosis between groups being compared, a problem called confounding by indication (6). Only under the assumption that these confounding factors are known and adequately measured in the study, is statistical adjustment in an observational setting possible. There is methodological literature showing that this assumption (no unknown or unmeasured confounding) is often not realistic in the context of studying interventions and that results from observational studies are not sufficiently valid to guide clinical practice. This applies just as much when more elaborate statistics, such as propensity scores, are applied (6). These methodological considerations apply to studies on RT for NFPAs and confounding is thus likely to hamper any verdict on the effect of RT in this context.

One, however, could argue that the evidence for a positive effect of RT is clear even in the absence of randomized trials (7). The apparent RT effect is reasonably large, and there is no doubt that this effect is larger than expected in the absence of treatment. Several singlearm studies (see Table 1) show long-term recurrence-free survival probabilities (>90\%) that are clearly higher than observed in the absence of RT (8); this seems to be the case for all RT modalities (9). Also, tumor shrinkage has been described after RT (10), a result unlikely to occur spontaneously in the absence of RT or an event such as apoplexy. One could, therefore, reasonably argue that RT does have a clear effect on the probability of tumor regrowth, despite only being studied in an observational setting.

This brings us to the next point. Even if we agree that RT reduces tumor regrowth risk, this is by no means a compelling argument for the use of postoperative RT because the endpoint studied, i.e. tumor growth, is of limited clinical value and not appropriate to guide treatment. 


\section{Studying the effect of radiotherapy: what is the relevant endpoint?}

In cancer research, there is some debate about the use of recurrence-free survival as an endpoint for drug effectiveness. This may sound surprising, but the crucial point is that recurrence-free survival does not automatically translate into a better overall survival (11). Lack of an increase in overall survival, especially in the absence of an improved quality of life, means that patients risk experiencing potential side effects of treatment without any potential health gain. It is for this reason that (direct or indirect) evidence of effect on overall survival and/ or quality of life is becoming more of a requirement in order for cancer drugs to be implemented in clinical care. An example of a discrepancy between progression-free survival (PFS) and overall survival is the use of extended chemotherapy for advanced non-small-cell lung cancer. While a clear effect on PFS has been shown (hazard ratio 0.75 ), this effect is much less pronounced for overall survival (hazard ratio 0.91) (12). Similarly, if rosiglitazone was shown to reduce HbA1C levels in patients with type 2 diabetes, this did not translate into reduced cardiovascular morbidity (13). Likewise, fluoride has been shown to increase bone mineral density, but also increased fracture risk (14).

One could argue that tumor control in the context of non-functioning adenomas is a surrogate endpoint, the reason being that small tumor growth is likely clinically irrelevant unless it negatively affects pituitary or visual function or quality of life. In other words, tumor growth per se is not relevant, as such growth does not automatically influence pituitary or visual outcomes negatively. This is especially true for adenomas without close relationship to the optic chiasm and only slow and marginal growth - such adenomas are not likely to induce clinically relevant morbidity (8). This crucial point is not considered when the sole endpoint is tumor regrowth. Therefore, the clinical benefit of RT cannot be inferred from the difference in tumor regrowth probability between patients with and patients without postoperative RT. Furthermore, it is an unwarranted assumption that lowering the risk of tumor regrowth will translate into a clinical benefit in terms of visual function or quality of life. A watchful waiting approach is a good alternative to postoperative RT, especially if careful follow-up is implemented. In addition, in the absence of apparent clinically relevant benefit, the patient undergoing RT may risk long-term side effects, such as hypopituitarism (see below).
The key question is: what could be considered a clinically relevant endpoint when studying RT in NFPAs studies? All potential benefits and disadvantages of RT should be taken into account for all endpoints under consideration. Clearly, mortality or overall survival would be important endpoints, as RT, but also tumor growth, can affect pituitary function, and pituitary dysfunction is related to mortality (15). However, a very large study would be required to answer, with adequate statistical power, the question of whether postoperative RT reduces mortality risk in NFPAs.

One reasonable option is to consider visual function as a relevant study outcome. This endpoint is directly relevant for the patient; but it also balances the potentially positive and negative effects of RT with respect to visual function. To our knowledge, data that compare visual outcomes between patients treated with and patients treated without postoperative RT are scarce. The second option, based on similar considerations as visual function, is pituitary function. The third option is general and disease-specific quality of life. Observational studies have not suggested that RT has a great impact (either positive or negative) on quality of life (16); however, there is a lack of randomized studies here also.

In summary, it can be argued that for evaluation of the effect of RT, tumor growth only is not a clinically relevant endpoint; more relevant endpoints are visual function, pituitary function or quality of life, preferably in combination. However, as it is likely that RT will not have a large effect on these endpoints (17), they can only be validly assessed in a randomized context, since subtle confounding may hamper judgment in an observational setting.

\section{Preventive radiotherapy for a benign condition?}

When the effect of RT for NFPAs is considered, this effect is often described in terms of recurrence risk or recurrencefree survival. Such terminology has the connotation of effects in cancer treatment, suggesting that recurrence is a major event in the disease course, undoubtedly related to morbidity and mortality. Arguably, this negative connotation of recurrence is not warranted in the context of NFPAs. These are benign tumors by definition, and the probability of pituitary adenomas displaying malignant potential is very low (18).

It is likely that pituitary macroadenomas are not completely resected during surgery, mainly because microscopic invasion is present in most macroadenomas at the time of surgery (19). Complete surgical removal of 
this microscopic invasion is not a reasonable option given the related risks, and unlike in many malignant tumors, a complete resection is not the hallmark of survival. Given these considerations, it is probably better to denote tumor growth after operation as regrowth and not recurrence for two reasons: firstly, it is likely that the tumor did regrow and not recur, and secondly, it avoids the cancerassociated term 'recurrence'.

There are several studies showing that in untreated NFPAs, approximately 50\% show growth after a follow-up period of 3-6 years (2). For surgically treated macroadenomas, the regrowth risk seems roughly similar (2; see also Table 1$)$. This is in line with the idea that macroadenomas are not resected completely and that the residual adenoma can still display growth behavior; it also suggests that the growth pattern after surgery is the same as before surgery.

Why intervene to prevent growth in a benign condition? As discussed before, no convincing evidence that relevant morbidity can be prevented exists. Importantly, even if relevant regrowth is observed, RT or a second surgical procedure are reasonable options, with good outcomes having been reported (20). However, it should be noted that late secondary intervention may be associated with worse pituitary outcome (21), underlying the need for close radiological follow-up and consideration of an intervention (RT or second surgery) when growth is observed.

\section{Radiotherapy and side effects}

If you hammer a nail in your laptop, would you be surprised if the laptop displays a decreased functioning? Probably not. The same holds true for therapies; no therapy is without potential for side effects, and RT is no exception.

It is well known that RT induces hypopituitarism, even if the exact risk and pattern is not clear. Studies have shown that in approximately $25 \%$ of patients, postoperative RT induces hypopituitarism; this risk is likely higher after a longer follow-up period (9). Importantly, the risk for hypopituitarism is approximately similar for conventional and non-conventional RT techniques $(5,9)$. RT-induced optic neuropathy is reported in $1-5 \%$ of patients and is likely dependent on the distance of the tumor from the optic chiasm (9). These side effects in themselves can be considered a relevant argument against routinely applied postoperative RT, as they represent the functions to be preserved by RT: visual and pituitary function. In short, the means may prevent the goals of RT.
The jury is still out with regard to the contribution of RT to development of cerebrovascular disease $(22,23)$. Two studies with longer periods of follow-up suggested an increased risk of RT-induced brain tumors, as after $>10$ years of follow-up, brain tumor was found in $2 \%$ of patients ( 24 , $25)$. However, these reported risks should be interpreted with caution as the necessary radiological follow-up in adenoma patients places them at higher risk for incidental findings of which the clinical relevance is not always clear. As such, studies require long-term follow-up ( $>10$ years) to detect these long-term problems, and studies reflecting new RT techniques are lacking. However, since compelling evidence for an overall positive and clinically relevant effect of postoperative RT is lacking, uncertainties regarding clinically relevant side effects (tumors, cerebrovascular events) should be considered when an indication for RT is discussed. The fact that the risk of many side effects increases with longer time since RT may be an argument to postpone it until tumor regrowth has been demonstrated. This postpones the timing of RT and thereby the risk of side effects; moreover, it will prevent unnecessary RT in approximately $50 \%$ of patients after surgery.

In summary, there is no compelling argument for routinely applying RT after surgery for NFPAs, as the benefit-risk balance is not convincingly positive.

\section{Arguments for the use of radiotherapy postoperatively}

\section{Radiotherapy is very effective on local tumor growth}

The efficacy of RT on reducing local tumor growth is indisputable, whatever the procedure used.

\section{Efficacy of fractionated conformal radiotherapy (FCRT)}

The long-term experience accumulated with RT for NFPAs essentially lies within older studies where postoperative FCRT was proposed routinely in some centers or in some patients for preventing recurrence or regrowth of tumor remnants. Mean PFS at 5 years postoperatively was $95 \%$ after FCRT compared to $70 \%$ in those who were not treated with RT $(8,20,26,27,28,29,30,31,32$, 33) (Table 1). This difference increases with the duration of follow-up, with mean PFS at 10 years being 50\% in patients without FCRT, compared to $>90 \%$ in patients treated with RT. At 15 years, PFS is $33 \%$ without RT vs $93 \%$ with RT (27); at 20 years, PFS after RT remains elevated at 92\% (34). 
Table 1 Main studies comparing the progression-free survival of patients treated or not treated with conventional radiotherapy.

\begin{tabular}{|c|c|c|}
\hline Author (year of publication) & $\begin{array}{c}\text { Number of } \\
\text { patients }\end{array}$ & $\begin{array}{c}\text { Median follow-up } \\
\text { (years) }\end{array}$ \\
\hline Jaffrain-Rea (1993) (25) & 57 & 7.1 \\
\hline Gittoes (1998) (26) & 126 & 9 \\
\hline Woollons (2000) (27) & 72 & 5.3 \\
\hline Park (2004) (19) & 176 & 4.3 \\
\hline Dekkers (2006) (7) & 109 & 6 \\
\hline Van den Bergh (2007) (28) & 122 & 8 \\
\hline Chang (2008) (29) & 352 & 8.4 \\
\hline Olsson (2009) (30) & 235 & 10 \\
\hline Brochier (2010) (31) & 142 & 6.9 \\
\hline Vargas (2015) (32) & 112 & 5 \\
\hline
\end{tabular}

\begin{tabular}{|c|c|}
\hline \multicolumn{2}{|c|}{ Number of patients } \\
\hline RT+ & RT- \\
\hline 24 & 33 \\
\hline 63 & 63 \\
\hline 50 & 22 \\
\hline 44 & 132 \\
\hline 6 & 103 \\
\hline 76 & 46 \\
\hline 277 & 75 \\
\hline 62 & 173 \\
\hline 15 & 127 \\
\hline 51 & 61 \\
\hline
\end{tabular}

\begin{tabular}{|c|c|}
\hline \multicolumn{2}{|c|}{$\begin{array}{l}\text { Progression-free } \\
\text { survival at } 5 \text { years }\end{array}$} \\
\hline RT+ & RT- \\
\hline 100 & 70 \\
\hline 93 & 68 \\
\hline 72 & 34 \\
\hline 98 & 85 \\
\hline 100 & 94 \\
\hline 95 & 49 \\
\hline 96 & 72 \\
\hline - & - \\
\hline 100 & 70 \\
\hline 96 & 71 \\
\hline
\end{tabular}

\begin{tabular}{|c|c|}
\hline \multicolumn{2}{|c|}{$\begin{array}{l}\text { Progression-free } \\
\text { survival at } 10 \text { years }\end{array}$} \\
\hline RT+ & RT- \\
\hline 96 & 55 \\
\hline 93 & 47 \\
\hline 98 & 50 \\
\hline 100 & 79 \\
\hline 95 & 22 \\
\hline 89 & 55 \\
\hline 94 & 62 \\
\hline 91 & 52 \\
\hline- & - \\
\hline
\end{tabular}

$\mathrm{RT}$, radiotherapy.

A meta-analysis confirms these results, demonstrating a relative risk of recurrence estimated at 1.97 (95\% CI, 1.15-3.35) in patients not treated with RT compared to irradiated patients (35).

\section{Efficacy of radiosurgery (SRS)}

Studies evaluating the effects of SRS are more recent (Table 2). In these studies, SRS was often not administered as routine postoperative adjuvant treatment but was administered only if a tumor remnant was present and growing or in case of recurrence. Nevertheless, PFS with
SRS is similar to that of focal radiation therapy (FRT), being on average $90-95 \%$ at 5 years and $85-90 \%$ at 10 years (36, $37,38,39,40,41,42,43,44,45,46,47,48,49,50,51$, $52,53,54,55,56,57)$. It must be noted, however, that the tumor mass in patients treated with SRS is generally smaller than in patients treated with FRT.

\section{Efficacy of fractionated stereotactic radiotherapy (FSRT)}

FSRT results in tumor control in an average of 95 and $90 \%$ of patients at 5 and 10 years, respectively $(54,58,59,60$, $61,62,63,64,65,66,67$ ) (Table 3).

Table 2 Main studies on stereotactic radiosurgery (SRS).

\begin{tabular}{|c|c|c|}
\hline Author (year of publication) & $\begin{array}{c}\text { Number of } \\
\text { patients }\end{array}$ & $\begin{array}{c}\text { Median follow-up } \\
\text { (months) }\end{array}$ \\
\hline Feigl (2002) (35) & 61 & 55.2 \\
\hline Wowra (2002) (36) & 30 & 55 \\
\hline Petrovich (2003) (37) & 56 & 36 \\
\hline Losa (2004) (38) & 52 & 41 \\
\hline Muacevic (2004) (39) & 51 & 21.7 \\
\hline Iwai (2005) (40) & 34 & 59.8 \\
\hline Picozzi (2005) (41) & 51 & 40.6 \\
\hline Mingione (2006) (42) & 100 & 44.9 \\
\hline Voges (2006) (43) & 37 & 56.6 \\
\hline Liscak (2007) (44) & 140 & 60 \\
\hline Pollock (2008) (45) & 62 & 64 \\
\hline Kobayashi (2009) (46) & 71 & 50.2 \\
\hline Hayashi (2010) (47) & 43 & 36 \\
\hline Gopalan (2011) (48) & 48 & 95 \\
\hline Iwata (2011) (49) & 100 & 33 \\
\hline Park (2011) (50) & 125 & 62 \\
\hline Starke (2012) (51) & 140 & 50 \\
\hline Runge (2012) (52) & 61 & 83 \\
\hline Wilson (2012) (53) & 51 & 50 \\
\hline Sheehan (2013) (54) & 512 & 36 \\
\hline Lee (2014) (55) & 41 & 48 \\
\hline $\operatorname{Bir}(2015)(56)$ & 57 & 45.5 \\
\hline
\end{tabular}

\begin{tabular}{|c|c|}
\hline SRS type & Dose (Gy) \\
\hline GK & 15 \\
\hline GK & 16 \\
\hline GK & 15 \\
\hline GK & 16.6 \\
\hline GK & 16.5 \\
\hline GK & 12.3 \\
\hline GK & 16.5 \\
\hline GK & 18.5 \\
\hline LINAC & 13.4 \\
\hline GK & 20 \\
\hline GK & 16 \\
\hline GK & 14.1 \\
\hline GK & 18.2 \\
\hline GK & 18.4 \\
\hline Cyber knife & 21 \\
\hline GK & 13 \\
\hline GK & 18 \\
\hline LINAC & 13 \\
\hline LINAC & 14 \\
\hline GK & 16 \\
\hline GK & 12 \\
\hline GK & 15 \\
\hline
\end{tabular}

\begin{tabular}{l} 
Tumor control (\%) \\
\hline 94 \\
93.3 (93 at 5 years) \\
100 \\
96.3 ( 88.2 at 5 years) \\
95 \\
87.1 (93 at 5 years) \\
96.1 \\
92.2 \\
100 \\
100 \\
96.8 ( 95 at 5 years) \\
96.7 \\
100 \\
83.3 \\
98 \\
90 ( 94 at 5 years) \\
89.6 ( 97 at 5 years) \\
98 \\
100 \\
93.4 ( 95 at 5 years) ( 85 at 10 years) \\
92.7 ( 85 at 10 years) \\
93 ( 90 at 10 years)
\end{tabular}

GK, gamma knife; LINAC, linear accelerator. 
Table 3 Main studies on fractional stereotactic radiotherapy (FSRT).

\begin{tabular}{l}
\hline Author (year of publication) \\
\hline Milker-Zabel (2001) (57) \\
Paek (2005) (58) \\
Colin (2005) (59) \\
Minniti (2006) (60) \\
Kong (2007) (61) \\
Schalin-Jantti (2010) (62) \\
Wilson (2012) (53) \\
Kopp (2013) (63) \\
Kim (2013) (64) \\
Minniti (2015) (65) \\
Barber (2016) (66)
\end{tabular}

\begin{tabular}{c}
\hline Number of patients \\
\hline 68 \\
68 \\
110 \\
92 \\
66 \\
30 \\
67 \\
37 \\
76 \\
68 \\
75
\end{tabular}

\begin{tabular}{c}
\hline Median follow-up (months) \\
\hline 38 \\
30 \\
48 \\
32 \\
36.7 \\
64 \\
60.1 \\
57 \\
80 \\
75 \\
72
\end{tabular}

\begin{tabular}{l}
\hline Dose (Gy) \\
\hline 50.4 \\
50 \\
50.4 \\
45 \\
50.4 \\
45 \\
50 \\
49.4 \\
50.4 \\
45 \\
54
\end{tabular}

\begin{tabular}{l} 
Tumor control $(\%)$ \\
\hline 93 at 5 years \\
98 at 5 years \\
99 at 5 years \\
98 at 5 years \\
97 \\
100 \\
93 at 5 years \\
91.9 \\
97.1 \\
97 at 5 years; 91 at 10 years \\
97.9
\end{tabular}

In summary, modern RT techniques (SRS and FSRT) seem to be as effective as more conventional RT on preventing tumor growth, with similar PFS. In terms of local tumor control, there is thus no clear evidence that one technique is preferable over the other. Rather, the choice is made according to adenoma size, proximity to the visual pathways and availability of the different procedures. If available, SRS is preferred if the adenoma maximal diameter is $<3 \mathrm{~cm}$ and is distant from the visual pathways to allow a $<8 \mathrm{~Gy}$ irradiation of the optic chiasm and nerves.

\section{Does radiotherapy improve visual function when impaired?}

While RT is clearly effective on tumor growth in terms of PFS, one criticism that can be made is that PFS is an imperfect clinical endpoint. In this context, visual function (visual acuity and visual field) may be considered as more relevant for evaluating RT efficacy, particularly in the case of large tumor remnants. Unfortunately, very few studies dealing with this endpoint have been published. Recently, Minniti et al. studied 34 NFPA patients with large postoperative tumor remnants ( $>3 \mathrm{~cm}$ maximal diameter) and visual disturbances who were treated with FSRT (66). FSRT not only achieved good local tumor control (PFS was $93 \%$ at 10 years and average tumor volume reduction was $47 \%$ ) but was also associated with visual improvement in 11 of the 34 patients, with deterioration being observed in only 2 patients (whose tumor volume had progressed) while visual function remained stable in the remaining patients (66).

Previous studies $(34,68,69)$ have also reported visual function improvement with RT. In a large series of patients with adenomas and postoperative visual impairment, RT was associated with an improvement in $55 \%$ of patients (34). In another series of patients with macroadenomas treated with RT alone, visual function improved in $78 \%$ after a median follow-up of 36 months (68).

\section{Could there be confounding factors in the evaluation of RT efficacy?}

Another criticism that could be made regarding the efficacy of RT is the retrospective design of the studies reported with their potential for confounding factors. Indeed, as the studies were uncontrolled, it could be supposed that choice of RT could have been based on tumor volume and visual consequences, with patient characteristics differing within treatment groups. In fact, it is likely that this bias tends to disadvantage RT, which is most often performed for the most aggressive adenomas with the highest growth potential, as reported by Chang et al. who showed that patients who were irradiated had adenomas that were larger $(30 \mathrm{~mm}$ vs $23 \mathrm{~mm}, P<0.001)$ and invaded the cavernous sinus more frequently $(P=0.004)$ compared to patients who were not irradiated (30).

\section{Despite potential adverse events, the benefit/risk ratio of radiotherapy remains favorable}

While RT is clearly effective in terms of local tumor control, it may be associated with side effects that need to be taken into account in the assessment of its benefit/ risk ratio.

\section{High incidence of hypopituitarism}

The main side effect of RT is the occurrence of anterior pituitary dysfunction. This risk is about 30 and $50 \%$ at 5 and 10 years after FCRT, respectively $(9,34,70)$. After SRS $(45,51,52,55)$, as after FSRT $(54,58,61,71)$, the risk at 5 years is $20-30 \%$. Thus, in the short term (5 years), RT does not seem to influence the risk of hypopituitarism. 
However, several recent publications $(72,73,74)$ have suggested that the risk of anterior pituitary deficiency was reduced if the dose delivered to the pituitary was more moderate. A cohort study performed by Marek et al. demonstrated that the incidence of new anterior pituitary deficiencies was reduced when the average dose administered to the normal pituitary was less than $15 \mathrm{~Gy}$ when compared to doses higher than $15 \mathrm{~Gy}$ (2.2 vs $72.5 \%$, $P<0.0001)(72)$.

However, the pejorative significance of hypopituitarism as an adverse event after RT is not the same if pituitary deficiencies already existed before RT. This is not so rare, as illustrated in the study by Dekkers et al. (8) who analyzed pituitary function in 109 operated nonfunctioning macroadenomas and found somatotroph, gonadotroph, corticotroph and thyrotroph deficiency in $83,90,60$ and $57 \%$ of patients, respectively; therefore, hypopituitarism was present in $94 \%$ of the patients and panhypopituitarism in $44 \%$ of them. It is clear that if patients already present with hypopituitarism, occurrence of pituitary dysfunction after RT carries less concern, which may shift the benefit/risk ratio.

\section{Optic neuropathy is very rare}

Another potential effect of RT is optic neuropathy. This side effect is very rare as it has been reported in less than $5 \%$ of cases for FCRT $(34,75,76)$. This risk is also very low $(\sim 3 \%)$ after SRS $(45,51,52,55)$ or FSRT $(54,58,61,71)$.

As for hypopituitarism, the risk of optic neuropathy can be reduced by limiting the radiation dose delivered to the optic pathways to $<8-10 \mathrm{~Gy}$. Indeed, the risk is significantly higher when the radiation dose is $>12 \mathrm{~Gy}$ $(77,78,79)$.

The occurrence of these rare visual adverse events needs to be counterbalanced by the potential visual improvement that can be observed thanks to reduction in tumor volume (as discussed earlier). Therefore, in terms of visual function, the benefit/risk ratio also appears to be positive $(66,68,69)$.

\section{Increased incidence of secondary brain tumors is unclear}

In the long term, older techniques of RT may be associated with an incidence of secondary brain tumor, estimated between 1.9 and $2.4 \%(24,25,34)$ after up to 20 years of follow-up. However, this increased risk was not confirmed in other studies $(80,81,82,83)$.
Increased risk of cerebrovascular events (CVES) is likely

In 1999, Brada et al. reported an increased risk of CVE (four-fold higher than the general population) in patients treated with RT (22). This increased risk was confirmed by other studies $(83,84,85,86)$, but at a lower degree and seemed to depend on the radiation dose: i.e., the risk is multiplied by 1.7 for doses between 45 and 50 Gy and by 3 for doses higher than 50 Gy) (86). Other studies did not confirm the association between irradiation and incidence of CVE $(87,88)$.

Improvement of RT procedures, and development of SRS and FSRT, allows for better modulation of intensity and delimitation of the irradiated volume to deliver high radiation doses on the target while sparing surrounding healthy tissues as much as possible. This is seemingly associated with a decreased incidence of the side effects discussed earlier. However, long-term data on new RT techniques that would be able to confirm these results are still lacking.

In summary, hypopituitarism is the main side effect of RT. The other side effects are much rarer, and their incidence is likely to decrease with newer RT techniques that spare irradiation of the healthy tissues surrounding the tumor as much as possible. Side effects appear to be moderate compared to the benefits provided by RT. The riskbenefit ratio increases when the risk of recurrence increases, particularly if the tumor remnant is important, exhibits rapid growth, is invasive, is close to the optic pathways with a risk of compression, or displays histological criteria of aggressiveness. Obviously, the presence of postoperative hypopituitarism will also facilitate the decision in favor of treatment with adjuvant RT.

\section{Are there options other than radiotherapy?}

In case of tumor remnant after initial surgery, the use of RT needs to be compared with other possible alternatives, such as watchful waiting, reoperation(s) and medical treatment. Indeed, it must be kept in mind that surgery is able to achieve complete resection of the adenoma in approximately $40 \%$ of cases $(89,90)$.

\section{Watchful waiting}

When the tumor has apparently been completely resected, PFS is $96 \%$ at 5 years and $82 \%$ at 10 years (90). Therefore, it seems reasonable, with regard to this low risk 
of recurrence, not to use routine RT for these patients and to propose simple surveillance.

In cases of incomplete resection, when a postoperative remnant persists, PFS is much lower. It is estimated at $56 \%$ at 5 years and $40 \%$ at 10 years with a tumor volume doubling time of 3.4 years (90). The tumor growth rate varies from one patient to another and is difficult to predict, with adenomas following different growth modelling (91). The risk of recurrence is increased when there is an invasive tumor (32) and when the tumor has histological criteria of proliferation as high Ki67 immunolabeling $(92,93)$.

If the remnant is of small volume, is distant from the visual pathways and without risk factors for tumor growth, the choice of watchful surveillance may be preferred. On the other hand, if the remnant is of larger volume, close to the optic pathways, and/or associated with histological criteria of aggressiveness, a more active management is required, either by second surgery or RT. Obviously, the surveillance option is only possible if regular neuroradiological evaluation is possible long term and the patient is compliant.

If tumor remnant growth is considered a good indication for RT, one important consideration is whether late RT (i.e., given only when tumor regrowth clearly represents a threat for important neighbor structures) or early RT (i.e., as soon as the tumor shows some growth potential), would be more beneficial for the patient. In other words, does early vs delayed postoperative RT provide the same clinical outcomes? In fact, there is no clear evidence that the timing of RT can influence the risk-benefit ratio. Several retrospective series did not show differences in terms of tumor control and toxicity between patients receiving immediate postoperative FCRT compared to those treated at the time of recurrence or progression $(58,61)$. By contrast, series reporting clinical outcomes after SRS suggest that early postoperative treatment may provide the best therapeutic option for patients with residual tumor, preventing the development of neurological deficits associated with tumor growth and reducing the risk of long-term toxicity $(42,94)$.

\section{Reoperation}

Reoperation may be an option in case of tumor regrowth or recurrence. However, it must be underlined that results obtained after a second operation are generally inferior to those obtained after the first operation: indeed, a remnant persists in $72 \%$ of cases and visual recovery is more rarely achieved (58 vs 90\%) (95). Moreover, there is a higher risk of complications (96), with an increased rate of diabetes insipidus (26 vs $16 \%, P=0.03$ ), cerebrospinal fluid leak (4 vs $1 \%, P=0.04$ ), meningitis ( 3 vs $0.4 \%, P=0.02$ ) and longer mean hospital stay (4.5 vs 2.8 days, $P=0.006$ ).

Reoperation seems indisputable when complete tumor resection can be expected (e.g., if the first operation was performed by a less experienced surgeon) or when symptomatic compression of the visual pathways persists (97). In the other situations, the use of RT may appear preferable, allowing good long-term tumor control associated with a relatively low risk of complications compared to those of reoperation. Reoperation may also be an option for debulking tumor remnants that are growing and/or recurrence for allowing either watchful waiting or more focused RT.

The presence of comorbidities is an important element to consider. The studies dealing with surgical management of pituitary adenomas in the elderly report the presence of associated comorbidities in $80 \%$ of cases $(98,99,100)$ and anesthetic score ASA $\geq 4$ in $10 \%$ of cases (99). In patients with severe comorbidity, elevated anesthetic risk and/or taking treatments that complicate the surgical procedure (antiplatelets agents, anticoagulants), RT may be preferred. There are few data on the efficacy and safety of pituitary radiotherapy in elderly patients. Ferrante et al. in 2002, in a cohort of patients older than 70 years, observed a tumor regrowth in only $5.8 \%$ of patients treated with radiotherapy compared to $13.6 \%$ of the patients who were not irradiated (101). Another study reports apparent better results in older patients, as a PFS at 10 years was $100 \%$ in patients over $60,98 \%$ in those aged between 40 and 60 and 93\% when under 40 (34).

On the other hand, it should be noted that age in itself does not seem to increase the postoperative complication risk $(100,102)$.

\section{Medical treatments}

Demonstration of dopamine and somatostatin receptors on the surface of NFPAs led to dopamine agonists and somatostatin analogues being proposed as potential medical therapies. However, very limited data on the efficacy of these treatments are currently available in the literature. The few available studies are retrospective, of short duration, and include only a limited number of patients; moreover, they are difficult to compare (variable inclusion criteria, treatment duration, treatment doses and assessment criteria) (103). Recently, some studies have reported efficacy of dopamine agonists in controlling tumor growth in some patients with NFPAs $(104,105)$. 
A prospective open-label randomized study has been reported very recently (106) showing that, after 2 years, residual tumor shrinkage, stabilization and enlargement were observed in 28.8, 66.1 and $5.1 \%$ of patients, respectively, in the cabergoline group and in 10.5, 73.7 and $15.8 \%$ of patients, respectively, in the control group $(P=0.01)$. On the contrary, neither somatostatin analogues nor gonadotropin-releasing hormone analogs are sufficiently effective to be proposed as an alternative to RT (103). Moreover, from an economic perspective, long-term medical treatment is generally more expensive than time-limited procedures like surgery or radiotherapy. To our knowledge, such studies have only been reported for acromegaly where relative costs of medical treatment was found to be more than 10-fold higher (107) but not for NFPAs.

\section{General conclusion}

Surgery remains the primary treatment of nonfunctioning pituitary macroadenomas. Nowadays, the excellent PFS after total removal of the tumor and the quality of pituitary imaging allow physicians to propose watchful waiting and to avoid immediate and routine postoperative RT. The main arguments against routinely applied RT after surgery are lack of evidence from randomized controlled trials, the use of clinically irrelevant endpoints in most studies on RT, the benign character of the condition, and potential side effects of RT. However, because of its excellent efficacy, and as side effects of RT seem to be limited, RT keeps a place in the management of NFPAs when a tumor remnant persists, particularly if it is invasive and displays high proliferation markers, if surveillance shows a relevant increase in tumor volume or if the tumor is close to the optic chiasm. In these cases, even when surgery is theoretically possible to delay RT or if medical therapy is feasible, RT remains the treatment of choice. RT is currently considered the best method of inhibiting tumor growth, reducing tumor volume and improving any existing visual defects. Since hypopituitarism is the main side effect of RT, treatment with RT may be chosen if a postoperative anterior pituitary deficit is already present at the time of treatment decision. The size of the remnant, its vicinity with the optic pathways and the potential risk to healthy surrounding tissues need to be considered when deciding on a RT procedure. SRS or FSR may be preferred, if available, but FCRT remains the RT procedure of choice in large rapidly evolving remnants.
Declaration of interest

The authors declare that there is no conflict of interest that could be perceived as prejudicing the impartiality of this debate.

\section{Funding}

This research did not receive any specific grant from any funding agency in the public, commercial or not-for-profit sector.

\section{References}

1 Chanson P, Raverot G, Castinetti F, Cortet-Rudelli C, Galland F \& Salenave $S$. Management of clinically non-functioning pituitary adenoma. Annales d'Endocrinologie 201576 239-247. (https://doi. org/10.1016/j.ando.2015.04.002)

2 Dekkers OM, Pereira AM \& Romijn JA. Treatment and follow-up of clinically nonfunctioning pituitary macroadenomas. Journal of Clinical Endocrinology and Metabolism 200893 3717-3726. (https:// doi.org/10.1210/jc.2008-0643)

3 Béclère $\mathrm{A}$. The radio-therapeutic treatment of tumors of the hypophysis, gigantism and agromegaly. Archives of the Roentgen Ray 190914 142-150. (https://doi.org/10.1259/arr.1909.0063)

4 Ronson BB, Schulte RW, Han KP, Loredo LN, Slater JM \& Slater JD. Fractionated proton beam irradiation of pituitary adenomas. International Journal of Radiation Oncology, Biology, Physics 200664 425-434. (https://doi.org/10.1016/j.ijrobp.2005.07.978)

5 Li X, Li Y, Cao Y, Li P, Liang B, Sun J \& Feng E. Safety and efficacy of fractionated stereotactic radiotherapy and stereotactic radiosurgery for treatment of pituitary adenomas: a systematic review and meta-analysis. Journal of the Neurological Sciences 2017372 110-116 (https://doi.org/10.1016/j.jns.2016.11.024)

6 Bosco JL, Silliman RA, Thwin SS, Geiger AM, Buist DS, Prout MN, Yood MU, Haque R, Wei F \& Lash TL. A most stubborn bias: no adjustment method fully resolves confounding by indication in observational studies. Journal of Clinical Epidemiology 201063 64-74. (https://doi.org/10.1016/j.jclinepi.2009.03.001)

7 Vandenbroucke JP When are observational studies as credible as randomised trials? Lancet 2004363 1728-1731. (https://doi. org/10.1016/S0140-6736(04)16261-2)

8 Dekkers OM, Pereira AM, Roelfsema F, Voormolen JH, Neelis KJ, Schroijen MA, Smit JW \& Romijn JA. Observation alone after transsphenoidal surgery for nonfunctioning pituitary macroadenoma. Journal of Clinical Endocrinology and Metabolism 2006 91 1796-1801. (https://doi.org/10.1210/jc.2005-2552)

9 Minniti G, Flickinger J, Tolu B \& Paolini S. Management of nonfunctioning pituitary tumors: radiotherapy. Pituitary 201821 154-161. (https://doi.org/10.1007/s11102-018-0868-4)

10 Narayan V, Mohammed N, Bir SC, Savardekar AR, Patra DP, Bollam P $\&$ Nanda A. Long-term outcome of nonfunctioning and hormonal active pituitary adenoma after gamma knife radiosurgery. World Neurosurgery 2018114 e824-e832. (https://doi.org/10.1016/j. wneu.2018.03.094)

11 Amir E, Seruga B, Kwong R, Tannock IF \& Ocana A. Poor correlation between progression-free and overall survival in modern clinical trials: are composite endpoints the answer? European Journal of Cancer 201248 385-388. (https://doi.org/10.1016/j.ejca.2011.10.028)

12 Soon YY, Stockler MR, Askie LM \& Boyer MJ. Duration of chemotherapy for advanced non-small-cell lung cancer: a systematic review and meta-analysis of randomized trials. Journal of Clinical Oncology 200927 3277-3283. (https://doi.org/10.1200/ JCO.2008.19.4522)

13 Nissen SE \& Wolski K. Effect of rosiglitazone on the risk of myocardial infarction and death from cardiovascular causes. New 
England Journal of Medicine 2007356 2457-2471. (https://doi org/10.1056/NEJMoa072761)

14 Rothwell PM External validity of randomised controlled trials: 'to whom do the results of this trial apply?'. Lancet 2005365 82-93. (https://doi.org/10.1016/S0140-6736(04)17670-8)

15 Tomlinson JW, Holden N, Hills RK, Wheatley K, Clayton RN, Bates AS, Sheppard MC \& Stewart PM. Association between premature mortality and hypopituitarism. West Midlands prospective hypopituitary study group. Lancet 2001357 425-431. (https://doi. org/10.1016/S0140-6736(00)04006-X)

16 van Beek AP, van den Bergh AC, van den Berg LM, van den Berg G, Keers JC, Langendijk JA \& Wolffenbuttel BH. Radiotherapy is not associated with reduced quality of life and cognitive function in patients treated for nonfunctioning pituitary adenoma. International Journal of Radiation Oncology, Biology, Physics 200768 986-991. (https://doi.org/10.1016/j.ijrobp.2007.01.017)

17 Glasziou P, Chalmers I, Rawlins M \& McCulloch P. When are randomised trials unnecessary? Picking signal from noise. BMJ 2007 334 349-351. (https://doi.org/10.1136/bmj.39070.527986.68)

18 Raverot G, Burman P, McCormack A, Heaney A, Petersenn S, Popovic V, Trouillas J, Dekkers OM \& European Society of Endocrinology. European Society of Endocrinology Clinical Practice Guidelines for the management of aggressive pituitary tumours and carcinomas. European Journal of Endocrinology 2018178 G1-G24. (https://doi.org/10.1530/EJE-17-0796)

19 Selman WR, Laws ER Jr, Scheithauer BW \& Carpenter SM. The occurrence of dural invasion in pituitary adenomas. Journal of Neurosurgery $1986 \mathbf{6 4}$ 402-407. (https://doi.org/10.3171/ jns.1986.64.3.0402)

20 Park P, Chandler WF, Barkan AL, Orrego JJ, Cowan JA, Griffith KA $\&$ Tsien C. The role of radiation therapy after surgical resection of nonfunctional pituitary macroadenomas. Neurosurgery 2004 55 100-106; discussion 106-107. (https://doi.org/10.1227/01. NEU.0000126885.71242.D7)

21 Pomeraniec IJ, Dallapiazza RF, Xu Z, Jane JA Jr \& Sheehan JP. Early versus late gamma knife radiosurgery following transsphenoidal resection for nonfunctioning pituitary macroadenomas: a matched cohort study. Journal of Neurosurgery 2016125 202-212. (https://doi. org/10.3171/2015.5.JNS15581)

22 Brada M, Burchell L, Ashley S \& Traish D. The incidence of cerebrovascular accidents in patients with pituitary adenoma. International Journal of Radiation Oncology, Biology, Physics 199945 693-698. (https://doi.org/10.1016/S0360-3016(99)00159-5)

23 Flickinger JC, Nelson PB, Taylor FH \& Robinson A. Incidence of cerebral infarction after radiotherapy for pituitary adenoma. Cancer 198963 2404-2408. (https://doi.org/10.1002/10970142(19890615)63:12<2404::AID-CNCR2820631205>3.0.CO;2-3)

24 Minniti G, Traish D, Ashley S, Gonsalves A \& Brada M. Risk of second brain tumor after conservative surgery and radiotherapy for pituitary adenoma: update after an additional 10 years. Journal of Clinical Endocrinology and Metabolism 200590 800-804. (https://doi. org/10.1210/jc.2004-1152)

25 Tsang RW, Laperriere NJ, Simpson WJ, Brierley J, Panzarella T \& Smyth HS. Glioma arising after radiation therapy for pituitary adenoma. A report of four patients and estimation of risk. Cancer 199372 2227-2233. (https://doi.org/10.1002/10970142(19931001)72:7<2227::AID-CNCR2820720727>3.0.CO;2-I)

26 Jaffrain-Rea ML, Derome P, Bataini JP, Thomopoulos P, Bertagna X \& Luton JP. Influence of radiotherapy on long-term relapse in clinically non-secreting pituitary adenomas. A retrospective Study (19701988). European Journal of Medicine 19932 398-403.

27 Gittoes NJL, Bates AS, Tse W, Bullivan B, Sheppard MC, Clayton RN \& Stewart PM. Radiotherapy for non-functioning pituitary tumours. Clinical Endocrinology 199848 331-337. (https://doi.org/10.1046/ j.1365-2265.1998.00393.x)
28 Woollons AC, Hunn MK, Rajapakse YR, Toomath R, Hamilton DA, Conaglen JV \& Balakrishnan V. Non-functioning pituitary adenomas: indications for postoperative radiotherapy. Clinical Endocrinology 200053 713-717. (https://doi.org/10.1046/j.13652265.2000.01153.x)

29 van den Bergh AC, van den Berg G, Schoorl MA, Sluiter WJ, van der Vliet AM, Hoving EW, Szabo BG, Langendijk JA, Wolffenbuttel BH $\&$ Dullaart RP. Immediate postoperative radiotherapy in residual nonfunctioning pituitary adenoma: beneficial effect on local control without additional negative impact on pituitary function and life expectancy. International Journal of Radiation Oncology, Biology, Physics 200767 863-869. (https://doi.org/10.1016/j. ijrobp.2006.09.049)

30 Chang EF, Zada G, Kim S, Lamborn KR, Quinones-Hinojosa A, Tyrrell JB, Wilson CB \& Kunwar S. Long-term recurrence and mortality after surgery and adjuvant radiotherapy for nonfunctional pituitary adenomas. Journal of Neurosurgery 2008108 736-745. (https://doi.org/10.3171/JNS/2008/108/4/0736)

31 Olsson DS, Buchfelder M, Schlaffer S, Bengtsson BA, Jakobsson KE, Johannsson G \& Nilsson AG. Comparing progression of nonfunctioning pituitary adenomas in hypopituitarism patients with and without long-term GH replacement therapy. European Journal of Endocrinology 2009161 663-669. (https://doi.org/10.1530/EJE-090572)

32 Brochier S, Galland F, Kujas M, Parker F, Gaillard S, Raftopoulos C, Young J, Alexopoulou O, Maiter D \& Chanson P. Factors predicting relapse of nonfunctioning pituitary macroadenomas after neurosurgery: a study of 142 patients. European Journal of Endocrinology 2010163 193-200. (https://doi.org/10.1530/EJE-100255)

33 Vargas G, Gonzalez B, Ramirez C, Ferreira A, Espinosa E, Mendoza V, Guinto G, Lopez-Felix B, Zepeda E \& Mercado M. Clinical characteristics and treatment outcome of 485 patients with nonfunctioning pituitary macroadenomas. International Journal of Endocrinology 20152015 756069. (https://doi. org $/ 10.1155 / 2015 / 756069$ )

34 Brada M, Rajan B, Traish D, Ashley S, Holmes-Sellors PJ, Nussey S \& Uttley D. The long-term efficacy of conservative surgery and radiotherapy in the control of pituitary adenomas. Clinical Endocrinology 199338 571-578. (https://doi. org/10.1111/j.1365-2265.1993.tb02137.x)

35 Murad MH, Fernandez-Balsells MM, Barwise A, Gallegos-Orozco JF, Paul A, Lane MA, Lampropulos JF, Natividad I, Perestelo-Perez L, Ponce de Leon-Lovaton PG et al. Outcomes of surgical treatment for nonfunctioning pituitary adenomas: a systematic review and meta-analysis. Clinical Endocrinology 201073 777-791. (https://doi. org/10.1111/j.1365-2265.2010.03875.x)

36 Feigl GC, Bonelli CM, Berghold A \& Mokry M. Effects of gamma knife radiosurgery of pituitary adenomas on pituitary function. Journal of Neurosurgery 200297 (5 Supplement) 415-421. (https://doi. org/10.3171/jns.2002.97.supplement)

37 Wowra B \& Stummer W. Efficacy of gamma knife radiosurgery for nonfunctioning pituitary adenomas: a quantitative follow up with magnetic resonance imaging-based volumetric analysis. Journal of Neurosurgery 200297 (5 Supplement) 429-432. (https://doi. org/10.3171/jns.2002.97.supplement)

38 Petrovich Z, Yu C, Giannotta SL, Zee CS \& Apuzzo ML. Gamma knife radiosurgery for pituitary adenoma: early results. Neurosurgery 200353 51-59; discussion 59-61. (https://doi.org/10.1227/01. NEU.0000068702.00330.47)

39 Losa M, Valle M, Mortini P, Franzin A, da Passano CF, Cenzato M, Bianchi S, Picozzi P \& Giovanelli M. Gamma knife surgery for treatment of residual nonfunctioning pituitary adenomas after surgical debulking. Journal of Neurosurgery 2004100 438-444. (https://doi.org/10.3171/jns.2004.100.3.0438) 
40 Muacevic A, Uhl E \& Wowra B. Gamma knife radiosurgery for nonfunctioning pituitary adenomas. Acta Neurochirurgica: Supplementum 200491 51-54.

41 Iwai Y, Yamanaka K, Yoshioka K, Yoshimura M, Honda Y, Matsusaka Y, Komiyama M \& Yasui T. The usefulness of adjuvant therapy using gamma knife radiosurgery for the recurrent or residua nonfunctioning pituitary adenomas. No Shinkei Geka: Neurological Surgery 200533 777-783.

42 Picozzi P, Losa M, Mortini P, Valle MA, Franzin A, Attuati L, Ferrari da Passano C \& Giovanelli M. Radiosurgery and the prevention of regrowth of incompletely removed nonfunctioning pituitary adenomas. Journal of Neurologicalsurgery 2005102 (Supplement) 71-74. (https://doi.org/10.3171/jns.2005.102.s_supplement.0071)

43 Mingione V, Yen CP, Vance ML, Steiner M, Sheehan J, Laws ER \& Steiner L. Gamma surgery in the treatment of nonsecretory pituitary macroadenoma. Journal of Neurosurgery $2006 \mathbf{1 0 4} 876-883$. (https:// doi.org/10.3171/jns.2006.104.6.876)

44 Voges J, Kocher M, Runge M, Poggenborg J, Lehrke R, Lenartz D, Maarouf M, Gouni-Berthold I, Krone W, Muller RP et al. Linear accelerator radiosurgery for pituitary macroadenomas: a 7-year follow-up study. Cancer 2006107 1355-1364. (https://doi. org/10.1002/cncr.22128)

45 Liscak R, Vladyka V, Marek J, Simonova G \& Vymazal J. Gamma knife radiosurgery for endocrine-inactive pituitary adenomas. Acta Neurochirurgica 2007149 999-1006. (https://doi.org/10.1007/s00701007-1253-7)

46 Pollock BE, Cochran J, Natt N, Brown PD, Erickson D, Link MJ, Garces YI, Foote RL, Stafford SL \& Schomberg PJ. Gamma knife radiosurgery for patients with nonfunctioning pituitary adenomas: results from a 15-year experience. International Journal of Radiation Oncology, Biology, Physics 200870 1325-1329. (https://doi. org/10.1016/j.ijrobp.2007.08.018)

47 Kobayashi T. Long-term results of stereotactic gamma knife radiosurgery for pituitary adenomas. Specific strategies for different types of adenoma. Progress in Neurological Surgery 200922 77-95. (https://doi.org/10.1159/000163384)

48 Hayashi M, Chernov M, Tamura N, Nagai M, Yomo S, Ochiai T, Amano K, Izawa M, Hori T, Muragaki Y et al. Gamma knife robotic microradiosurgery of pituitary adenomas invading the cavernous sinus: treatment concept and results in 89 cases. Journal of NeuroOncology 201098 185-194. (https://doi.org/10.1007/s11060-0100172-2)

49 Gopalan R, Schlesinger D, Vance ML, Laws E \& Sheehan J. Longterm outcomes after gamma knife radiosurgery for patients with a nonfunctioning pituitary adenoma. Neurosurgery $201169284-293$. (https://doi.org/10.1227/NEU.0b013e31821bc44e)

50 Iwata H, Sato K, Tatewaki K, Yokota N, Inoue M, Baba Y \& Shibamoto Y. Hypofractionated stereotactic radiotherapy with CyberKnife for nonfunctioning pituitary adenoma: high local control with low toxicity. Neuro-Oncology 201113 916-922. (https:// doi.org/10.1007/s00701-007-1253-7)

51 Park KJ, Kano H, Parry PV, Niranjan A, Flickinger JC, Lunsford LD \& Kondziolka D. Long-term outcomes after gamma knife stereotactic radiosurgery for nonfunctional pituitary adenomas. Neurosurgery 201169 1188-1199. (https://doi.org/10.1227/ NEU.0b013e318222afed)

52 Starke RM, Williams BJ, Jane JA Jr \& Sheehan JP. Gamma knife surgery for patients with nonfunctioning pituitary macroadenomas: predictors of tumor control, neurological deficits, and hypopituitarism. Journal of Neurosurgery 2012117 129-135. (https:// doi.org/10.3171/2012.4.JNS112250)

53 Runge MJR, Maarouf M, Hunsche S, Kocher M, Ruge MI, El Majdoub F, Treuer H, Mueller R-P, Voges J \& Sturm V. LINACradiosurgery for nonsecreting pituitary adenomas. Strahlentherapie und Onkologie 2012188 319-327. (https://doi.org/10.1007/s00066011-0052-5)
54 Wilson PJ, De-Loyde KJ, Williams JR \& Smee RI. A single centre's experience of stereotactic radiosurgery and radiotherapy for nonfunctioning pituitary adenomas with the linear accelerator (Linac). Journal of Clinical Neuroscience 201219 370-374. (https://doi. org/10.1016/j.jocn.2011.07.025)

55 Sheehan JP, Starke RM, Mathieu D, Young B, Sneed PK, Chiang VL, Lee JYK, Kano H, Park KJ, Niranjan A et al. Gamma knife radiosurgery for the management of nonfunctioning pituitary adenomas: a multicenter study. Journal of Neurosurgery 2013119 446-456. (https:// doi.org/10.3171/2013.3.JNS12766)

56 Lee CC, Kano H, Yang HC, Xu Z, Yen CP, Chung WY, Pan DH, Lunsford LD \& Sheehan JP. Initial gamma knife radiosurgery for nonfunctioning pituitary adenomas. Journal of Neurosurgery 2014120 647-654. (https://doi.org/10.3171/2013.11.JNS131757)

57 Bir SC, Murray RD, Ambekar S, Bollam P \& Nanda A. Clinical and radiologic outcome of gamma knife radiosurgery on nonfunctioning pituitary adenomas. Journal of Neurological Surgery: Part B, Skull Base 201576 351-357. (https://doi.org/10.1055/s-0035-1549309)

58 Milker-Zabel S, Debus J, Thilmann C, Schlegel W \& Wannenmacher M. Fractionated stereotactically guided radiotherapy and radiosurgery in the treatment of functional and nonfunctional adenomas of the pituitary gland. International Journal of Radiation Oncology, Biology, Physics 200150 1279-1286. (https://doi. org/10.1016/S0360-3016(01)01535-8)

59 Paek KI, Kim SH, Song SH, Choi SW, Koh HS, Youm JY \& Kim Y. Clinical significance of Ki-67 labeling index in pituitary macroadenoma. Journal of Korean Medical Science 200520 489-494. (https://doi.org/10.3346/jkms.2005.20.3.489)

60 Colin P, Jovenin N, Delemer B, Caron J, Grulet H, Hecart AC, Lukas C, Bazin A, Bernard MH, Scherpereel B et al. Treatment of pituitary adenomas by fractionated stereotactic radiotherapy: a prospective study of 110 patients. International Journal of Radiation Oncology, Biology, Physics 200562 333-341. (https://doi. org/10.1016/j.ijrobp.2004.09.058)

61 Minniti G, Traish D, Ashley S, Gonsalves A \& Brada M. Fractionated stereotactic conformal radiotherapy for secreting and nonsecreting pituitary adenomas. Clinical Endocrinology 200664 542-548. (https:// doi.org/10.1111/j.1365-2265.2006.02506.x)

62 Kong DS, Lee JI, Lim DH, Kim KW, Shin HJ, Nam DH, Park K \& Kim JH. The efficacy of fractionated radiotherapy and stereotactic radiosurgery for pituitary adenomas. Cancer $2007110854-860$. (https://doi.org/10.1002/cncr.22860)

63 Schalin-Jantti C, Valanne L, Tenhunen M, Setala K, Paetau A, Sane T $\&$ Kouri M. Outcome of fractionated stereotactic radiotherapy in patients with pituitary adenomas resistant to conventional treatments: a 5.25-year follow-up study. Clinical Endocrinology 2010 73 72-77. (https://doi.org/ 10.1111/j.1365-2265.2009.03755.x)

64 Kopp C, Theodorou M, Poullos N, Astner ST, Geinitz H, Stalla GK, Meyer B, Molls M, Nieder C \& Grosu A-L. Fractionated stereotactic radiotherapy in the treatment of pituitary adenomas. Strahlentherapie und Onkologie 2013189 932-937. (https://doi.org/10.1007/s00066013-0433-z)

65 Kim JO, Ma R, Akagami R, McKenzie M, Johnson M, Gete E $\&$ Nichol A. Long-term outcomes of fractionated stereotactic radiation therapy for pituitary adenomas at the BC Cancer Agency. International Journal of Radiation Oncology, Biology, Physics 201387 528-533. (https://doi.org/10.1016/j.ijrobp.2013.06.2057)

66 Minniti G, Scaringi C, Poggi M, Jaffrain Rea ML, Trillo G, Esposito V, Bozzao A, Enrici MM, Toscano V \& Enrici RM. Fractionated stereotactic radiotherapy for large and invasive non-functioning pituitary adenomas: long-term clinical outcomes and volumetric MRI assessment of tumor response. European Journal of Endocrinology 2015 172 433-441. (https://doi.org/10.1530/EJE-14-0872)

67 Barber SM, Teh BS \& Baskin DS. Fractionated stereotactic radiotherapy for pituitary adenomas. Neurosurgery 201679 406-417. (https://doi.org/10.1227/NEU.0000000000001155) 
68 Rush SC \& Newall J. Pituitary adenoma: the efficacy of radiotherapy as the sole treatment. International Journal of Radiation Oncology, Biology, Physics 198917 165-169. (https://doi.org/10.1016/03603016(89)90384-2)

69 Colao A, Cerbone G, Cappabianca P, Ferone D, Alfieri A, Di Salle F, Faggiano A, Merola B, de Divitiis E \& Lombardi G. Effect of surgery and radiotherapy on visual and endocrine function in nonfunctioning pituitary adenomas. Journal of Endocrinological Investigation 199821 284-290. (https://doi.org/10.1007/BF03350330)

70 Rim CH, Yang DS, Park YJ, Yoon WS, Lee JA \& Kim CY. Radiotherapy for pituitary adenomas: long-term outcome and complications. Radiation Oncology Journal 201129 156-163. (https://doi. org/10.3857/roj.2011.29.3.156)

71 Paek SH, Downes MB, Bednarz G, Keane WM, WernerWasik M, Curran WJ Jr \& Andrews DW. Integration of surgery with fractionated stereotactic radiotherapy for treatment of nonfunctioning pituitary macroadenomas. International Journal of Radiation Oncology, Biology, Physics 200561 795-808. (https://doi. org/10.1016/j.ijrobp.2004.07.688)

72 Marek J, Jezkova J, Hana V, Krsek M, Bandurova L, Pecen L, Vladyka V \& Liscak R. Is it possible to avoid hypopituitarism after irradiation of pituitary adenomas by the Leksell gamma knife? European Journal of Endocrinology 2011164 169-178. (https://doi. org/10.1530/EJE-10-0733)

73 Sicignano G, Losa M, del Vecchio A, Cattaneo GM, Picozzi P, Bolognesi A, Mortini P \& Calandrino R. Dosimetric factors associated with pituitary function after gamma knife surgery (GKS) of pituitary adenomas. Radiotherapy and Oncology 2012104 119-124. (https:// doi.org/10.1016/j.radonc.2012.03.021)

74 Ikeda H, Jokura H \& Yoshimoto T. Transsphenoidal surgery and adjuvant gamma knife treatment for growth hormone-secreting pituitary adenoma. Journal of Neurosurgery 200195 285-291. (https:// doi.org/10.3171/jns.2001.95.2.0285)

75 Tsang RW, Brierley JD, Panzarella T, Gospodarowicz MK, Sutcliffe SB $\&$ Simpson WJ. Radiation therapy for pituitary adenoma: treatment outcome and prognostic factors. International Journal of Radiation Oncology, Biology, Physics 199430 557-565. (https://doi. org/10.1016/0360-3016(92)90941-A)

76 Zierhut D, Flentje M, Adolph J, Erdmann J, Raue F \& Wannenmacher M. External radiotherapy of pituitary adenomas. International Journal of Radiation Oncology, Biology, Physics 199533 307-314. (https://doi.org/10.1016/0360-3016(95)00071-6)

77 Stafford SL, Pollock BE, Leavitt JA, Foote RL, Brown PD, Link MJ, Gorman DA \& Schomberg PJ. A study on the radiation tolerance of the optic nerves and chiasm after stereotactic radiosurgery. International Journal of Radiation Oncology, Biology, Physics 200355 1177-1181. (https://doi.org/10.1016/S0360-3016(02)04380-8)

78 Mayo C, Martel MK, Marks LB, Flickinger J, Nam J \& Kirkpatrick J. Radiation dose-volume effects of optic nerves and chiasm. International Journal of Radiation Oncology, Biology, Physics 201076 (3 Supplement) S28-S35. (https://doi.org/10.1016/j. ijrobp.2009.07.1753)

79 Pollock BE, Link MJ, Leavitt JA \& Stafford SL. Dose-volume analysis of radiation-induced optic neuropathy after single-fraction stereotactic radiosurgery. Neurosurgery 201475 456-460; discussion 460. (https://doi.org/10.1227/NEU.0000000000000457)

80 Bliss P, Kerr GR \& Gregor A. Incidence of second brain tumours after pituitary irradiation in Edinburgh 1962-1990. Clinical Oncology 1994 6 361-363. (https://doi.org/10.1016/S0936-6555(05)80187-6)

81 Erfurth EM, Bulow B, Mikoczy Z \& Hagmar L. Incidence of a second tumor in hypopituitary patients operated for pituitary tumors. Journal of Clinical Endocrinology and Metabolism 200186 659-662. (https://doi.org/10.1210/jcem.86.2.7234)

82 Sattler MG, van Beek AP, Wolffenbuttel BH, van den Berg G, Sluiter WJ, Langendijk JA \& van den Bergh AC. The incidence of second tumours and mortality in pituitary adenoma patients treated with postoperative radiotherapy versus surgery alone. Radiotherapy and Oncology 2012104 125-130. (https://doi.org/10.1016/j. radonc.2012.04.024)

83 van Varsseveld NC, van Bunderen CC, Ubachs DHH, Franken AAM, Koppeschaar HPF, van der Lely AJ \& Drent ML. Cerebrovascular events, secondary intracranial tumors, and mortality after radiotherapy for nonfunctioning pituitary adenomas: a subanalysis from the Dutch National Registry of Growth Hormone Treatment in Adults. Journal of Clinical Endocrinology and Metabolism 2015100 1104-1112. (https://doi.org/10.1210/jc.2014-3697)

84 Brada M, Ashley S, Ford D, Traish D, Burchell L \& Rajan B. Cerebrovascular mortality in patients with pituitary adenoma. Clinical Endocrinology 200257 713-717. (https://doi.org/10.1046/ j.1365-2265.2002.01570.x)

85 Erridge SC, Conkey DS, Stockton D, Strachan MWJ, Statham PFX, Whittle IR, Grant R, Kerr GR \& Gregor A. Radiotherapy for pituitary adenomas: long-term efficacy and toxicity. Radiotherapy and Oncology 200993 597-601. (https://doi.org/10.1016/j. radonc.2009.09.011)

86 Ayuk J. Does pituitary radiotherapy increase the risk of stroke and, if so, what preventative actions should be taken? Clinical Endocrinology 201276 328-331. (https://doi.org/10.1111/j.13652265.2011.04300.x)

87 Erfurth EM, Bulow B, Svahn-Tapper G, Norrving B, Odh K, Mikoczy Z, Bjork J \& Hagmar L. Risk factors for cerebrovascular deaths in patients operated and irradiated for pituitary tumors. Journal of Clinical Endocrinology and Metabolism $2002874892-4899$. (https://doi.org/10.1210/jc.2002-020526)

88 Sattler MG, Vroomen PC, Sluiter WJ, Schers HJ, van den Berg G, Langendijk JA, Wolffenbuttel BH, van den Bergh AC \& van Beek AP. Incidence, causative mechanisms, and anatomic localization of stroke in pituitary adenoma patients treated with postoperative radiation therapy versus surgery alone. International Journal of Radiation Oncology, Biology, Physics 201387 53-59. (https://doi. org/10.1016/j.ijrobp.2013.05.006)

89 Roelfsema F, Biermasz NR \& Pereira AM. Clinical factors involved in the recurrence of pituitary adenomas after surgical remission: a structured review and meta-analysis. Pituitary 201215 71-83. (https://doi.org/10.1007/s11102-011-0347-7)

90 Chen Y, Wang CD, Su ZP, Chen YX, Cai L, Zhuge QC \& Wu ZB. Natural history of postoperative nonfunctioning pituitary adenomas: a systematic review and meta-analysis. Neuroendocrinology 201296 333-342. (https://doi.org/10.1159/000339823)

91 Honegger J, Zimmermann S, Psaras T, Petrick M, Mittelbronn M, Ernemann U, Reincke M \& Dietz K. Growth modelling of nonfunctioning pituitary adenomas in patients referred for surgery. European Journal of Endocrinology 2008158 287-294. (https://doi. org/10.1530/EJE-07-0502)

92 Honegger J, Prettin C, Feuerhake F, Petrick M, Schulte-Monting J \& Reincke M. Expression of Ki-67 antigen in nonfunctioning pituitary adenomas: correlation with growth velocity and invasiveness. Journal of Neurosurgery 200399 674-679. (https://doi.org/10.3171/ jns.2003.99.4.0674)

93 Hsu CY, Guo WY, Chien CP \& Ho DM. MIB-1 labeling index correlated with magnetic resonance imaging detected tumor volume doubling time in pituitary adenoma. European Journal of Endocrinology 2010162 1027-1033. (https://doi.org/10.1530/EJE-09-1100)

94 Pomeraniec IJ, Kano H, Xu Z, Nguyen B, Siddiqui ZA, Silva D, Sharma M, Radwan H, Cohen JA, Dallapiazza RF et al. Early versus late gamma knife radiosurgery following transsphenoidal surgery for nonfunctioning pituitary macroadenomas: a multicenter matchedcohort study. Journal of Neurosurgery 2018129 648-657. (https://doi. org/10.3171/2017.5.JNS163069)

95 Cortet-Rudelli C, Bonneville JF, Borson-Chazot F, Clavier L, Coche Dequeant B, Desailloud R, Maiter D, Rohmer V, Sadoul JL, Sonnet E et al. Post-surgical management of non-functioning pituitary 
adenoma. Annales d'Endocrinologie 201576 228-238. (https://doi. org/10.1016/j.ando.2015.04.003)

96 Jahangiri A, Wagner J, Han SW, Tran MT, Miller LM, Tom MW, Ostling LR, Kunwar S, Blevins L \& Aghi MK. Rate and time course of improvement in endocrine function after more than 1000 pituitary operations. Neurosurgery 201461 (Supplement 1) 163-166. (https:// doi.org/10.1227/NEU.0000000000000405)

97 Sheehan J, Lee CC, Bodach ME, Tumialan LM, Oyesiku NM, Patil CG, Litvack Z, Zada G \& Aghi MK. Congress of neurological surgeons systematic review and evidence-based guideline for the management of patients with residual or recurrent nonfunctioning pituitary adenomas. Neurosurgery 201679 E539-E540. (https://doi. org/10.1227/NEU.0000000000001385)

98 Hong J, Ding X \& Lu Y. Clinical analysis of 103 elderly patients with pituitary adenomas: transsphenoidal surgery and follow-up. Journal of Clinical Neuroscience 200815 1091-1095. (https://doi. org/10.1016/j.jocn.2007.11.003)

99 Locatelli M, Bertani G, Carrabba G, Rampini P, Zavanone M, Caroli M, Sala E, Ferrante E, Gaini SM, Spada A et al. The transsphenoidal resection of pituitary adenomas in elderly patients and surgical risk. Pituitary 201316 146-151. (https://doi.org/10.1007/ s11102-012-0390-z)

100 Yunoue S, Tokimura H, Tominaga A, Fujio S, Karki P, Usui S, Kinoshita Y, Habu M, Moinuddin FM, Hirano H et al. Transsphenoidal surgical treatment of pituitary adenomas in patients aged 80 years or older. Neurosurgical Review 201437 269-277; discussion 269-277. (https://doi.org/10.1007/s10143-013-0509-3)

101 Ferrante L, Trillo G, Ramundo E, Celli P, Jaffrain-Rea ML, Salvati M, Esposito V, Roperto R, Osti MF \& Minniti G. Surgical treatment of pituitary tumors in the elderly: clinical outcome and long-term follow-up. Journal of Neuro-Oncology 200260 185-191. (https://doi. org/10.1023/A:1020652604014)

102 Azab MA, O'Hagan M, Abou-Al-Shaar H, Karsy M, Guan J \& Couldwell WT. Safety and outcome of transsphenoidal pituitary adenoma resection in elderly patients. World Neurosurgery 2019122 e1252-e1258. (https://doi.org/10.1016/j.wneu.2018.11.024)

103 Colao A, Di Somma C, Pivonello R, Faggiano A, Lombardi G \& Savastano S. Medical therapy for clinically non-functioning pituitary adenomas. Endocrine-Related Cancer 200815 905-915. (https://doi. org/10.1677/ERC-08-0181)

104 Greenman Y, Cooper O, Yaish I, Robenshtok E, Sagiv N, JonasKimchi T, Yuan X, Gertych A, Shimon I, Ram Z et al. Treatment of clinically nonfunctioning pituitary adenomas with dopamine agonists. European Journal of Endocrinology 2016175 63-72. (https:// doi.org/10.1530/EJE-16-0206)

105 Vieira Neto L, Wildemberg LE, Moraes AB, Colli LM, Kasuki L, Marques NV, Gasparetto EL, de Castro M, Takiya CM \& Gadelha MR. Dopamine receptor subtype 2 expression profile in nonfunctioning pituitary adenomas and in vivo response to cabergoline therapy. Clinical Endocrinology 201582 739-746. (https://doi.org/10.1111/cen.12684)

106 Batista RL, Musolino NRC, Cescato VAS, da Silva GO, Medeiros RSS, Herkenhoff CGB, Trarbach EB \& Cunha-Neto MB. Cabergoline in the management of residual nonfunctioning pituitary adenoma: a singlecenter, open-label, 2-year randomized clinical trial. American Journal of Clinical Oncology 201942 221-227. (https://doi.org/10.1097/ COC.0000000000000505)

107 Marko NF, LaSota E, Hamrahian AH \& Weil RJ. Comparative effectiveness review of treatment options for pituitary microadenomas in acromegaly. Journal of Neurosurgery $2012 \mathbf{1 1 7}$ 522-538. (https://doi.org/10.3171/2012.4.JNS11739)

Received 25 January 2019

Revised version received 21 April 2019

Accepted 1 May 2019 